J. Dairy Sci. 92:4792-4796

doi:10.3168/jds.2009-2215

(c) American Dairy Science Association, 2009.

\title{
Farm and factory production of goat cheese whey results in distinct chemical composition ${ }^{1}$
}

\author{
I. Moreno-Indias, ${ }^{*}$ N. Castro, ${ }^{*}$ A. Morales-delaNuez, ${ }^{*}$ D. Sánchez-Macías, ${ }^{*}$ P. Assunção,† J. Capote,ł \\ and A. Argüello*2 \\ *Department of Animal Science, Las Palmas de Gran Canaria University, Arucas 35413, Spain \\ †Instituto Tecnológico de Canarias, Santa Lucía de Tirajana, Las Palmas \\ $\ddagger$ Canary Agronomic Science Institute, La Laguna, Tenerife, Spain
}

\section{ABSTRACT}

To analyze differences in fat and protein content in cheese whey $(\mathrm{CW})$ manufactured in cheese-making factories and farms, goat $\mathrm{CW}$ samples were obtained from 60 cheese-making farms and 20 cheese factories. Gross composition of samples was analyzed by using an MIRIS device (MIRIS Inc., Uppsala, Sweden), whey protein composition was subjected to electrophoretic analysis, and fatty acid composition was analyzed via gas chromatography. Goat CW from farms contained higher dry matter content (70.6 vs. $50.8 \mathrm{~g} / \mathrm{L}$, farms vs. cheese factories, respectively) and a higher fat percentage ( 10.5 vs. $1.2 \%$ over dry matter, farms vs. cheese factories, respectively) than $\mathrm{CW}$ from cheese factories. Analysis of individual proteins showed that CW from farms contained higher concentrations of lactoferrin (0.4 vs. $0.2 \mathrm{mg} / \mathrm{mL}$ of $\mathrm{CW}$, farms vs. cheese factories, respectively) and caprine serum albumin (0.6 vs. 0.4 $\mathrm{mg} / \mathrm{mL}$ of whey, farms vs. cheese factories, respectively) than $\mathrm{CW}$ from cheese factories. No differences were observed in the fatty acid profile. The main fatty acids present in goat CW were C16:0, C18:1, C14:0, and C18:0. Thus, the origin of CW affects gross composition and the protein profile, but not the fatty acid profile.

Key word: cheese whey, goat, farm, factory

\section{INTRODUCTION}

Cheese production around the world occurs mainly in cheese factories, but in some areas, small-scale production of cheese using traditional methods is predominant. Whey is the major by-product in the manufacture of

Received March 15, 2009.

Accepted June 8, 2009.

${ }^{1}$ This work was supported by grant AGL 2006-08444/GAN from the Spanish Government.

${ }^{2}$ Corresponding author: aarguello@dpat.ulpgc.es cheese or CN from milk, representing 80 and $90 \%$ of the volume of transformed milk. Whey contains approximately $4.5 \%$ (wt/vol) lactose, $0.8 \%$ (wt/vol) protein, $1 \%$ (wt/vol) salts, and 0.1 to $0.8 \%$ (wt/vol) lactic acid (Yang et al., 1994). The quantity of cheese produced in the Canary Islands of Spain in 2007 was $20 \times 10^{6} \mathrm{~kg}$, and approximately $80 \%$ of this quantity was produced on farms (Fresno et al., 1992). Goat cheeses are manufactured with fresh milk, and coagulation times vary from 30 to $60 \mathrm{~min}$. The cheese whey $(\mathbf{C W})$ produced using traditional methods is usually spilled into the sinks.

Kaur et al. (2009) defined CW as a pollutant because of its high biological oxygen demand and because disposal can be costly. However, because of the significant amount of lactose present in whey and whey permeates, it can be treated with the enzyme lactase and concentrated into syrup for use as a sweetener in various food products. Lactose consists of a high proportion (75\%) of the total whey solids and is the main reason dairy whey is considered one of the most polluting food byproducts or co-products (biochemical oxygen demand $=35 \mathrm{~g} / \mathrm{kg}$; chemical oxygen demand $=60 \mathrm{~g} / \mathrm{kg}$; Bullerman and Berry, 1966; Siso, 1996).

This work was performed in the Canary Islands of Spain, where CW is traditionally manufactured on farms, rather than in cheese factories. Thus, knowledge of differences between the 2 sources of $\mathrm{CW}$ is essential. No data regarding differences in CW composition related to origin are currently available. Thus, the current study was carried out to compare the chemical composition (proximate analysis, main protein distribution, fatty acid profile) of CW produced on farms and in cheese factories.

\section{MATERIALS AND METHODS}

\section{Samples}

Eighty goat CW samples were obtained from 60 cheese-making farms and 20 cheese factories in the 
Canary Islands. Samples were obtained by the cheese manufacturer and refrigerated for $24 \mathrm{~h}$, after which they were transported to the laboratory and frozen $\left(-80^{\circ} \mathrm{C}\right)$ for further analysis. Briefly, the following cheese technologies were used on farms and factories. After milking on farms, unprocessed goat milk is coagulated with traditional rennet (from goat kids), and after 45 to 60 min, curds are cut with wire knives. The procedure in cheese factories is similar. Goat milk is pasteurized $\left(75^{\circ} \mathrm{C}\right.$ for $\left.15 \mathrm{~s}\right)$, and after the milk is cooled, coagulation is performed with commercial rennet (50\% chymosin, $50 \%$ pepsin). After 30 to $45 \mathrm{~min}$, curds are cut with wire knives.

\section{Compositional Analysis}

Total protein, fat, lactose, and TS were measured in CW samples with an MIRIS device (MIRIS Inc., Uppsala, Sweden). The MIRIS device is based on the mid-infrared technique approved by the International Dairy Federation (Brussels, Belgium) and AOAC International (Gaithersburg, MD). No special calibrations for whey were necessary.

\section{Electrophoresis}

Whey protein from untreated liquid whey was subjected to SDS-PAGE analysis by the method of Laemmli (1970; 4.2\% stacking gel, 19:1 acrylamide:bisacrylamide; $12.5 \%$ separating gel, 24:1 acrylamide:bisacrylamide) by using a Protean II Cell electrophoresis unit (BioRad Laboratories, Hercules, CA). Lactoferrin, serum caprine albumin, $\alpha_{\mathrm{s}}-\mathrm{CN}, \beta-\mathrm{CN}, \kappa-\mathrm{CN}, \beta-\mathrm{LG}$, and $\alpha$-LA (Sigma Chemical Co., St. Louis, MO) were used as standards. The exponential curve generated using the standards encompassed the range of protein concentrations encountered in all samples. Samples and appropriate standards were denatured at $100^{\circ} \mathrm{C}$ for 5 min in Tris. $\mathrm{HCl}, \mathrm{pH} 6.8$, containing $1 \%$ SDS (wt/vol) and $4 \%$ 2-mercaptoethanol. Immediately after loading the samples and standards, gels were run at $30 \mathrm{~mA}$ until the leading bands were approximately $1 \mathrm{~cm}$ from the bottom of the gel. Gels were immediately removed from the plates and placed in a fixative solution of $40 \%$ methanol (vol/vol) and 10\% TCA (wt/vol). Gels were then stained as described by Basch et al. (1985). Gels were destained in a solution containing $40 \%$ methanol (vol/vol) and $10 \%$ acetic acid (vol/vol). Protein bands were quantified with a Quantity One apparatus (BioRad Laboratories). The integrated densities of the sample bands were compared with known standards and converted to percentage of total whey protein from the gross compositional analysis. Values for individual whey proteins are the means of data from 3 gels.

\section{Fatty Acids}

Milk fat was extracted according to the Röse-Gottlieb method, and fatty acid methyl esters were obtained as described by Chin et al. (1992). Separation and quantification of the methyl esters were carried out on a gas chromatograph (Varian 3600; Varian, Harbor City, CA) equipped with a split-splitless injector and a flameionization detector. Methyl ester separation was carried out on a capillary column SP2560 $(100 \mathrm{~m} \times 0.25 \mathrm{~mm}$ i.d., $0.25 \mu \mathrm{m}$ phase thickness; Supelco Inc., Bellefonte, PA) with helium as the carrier gas $(331 \mathrm{kPa})$. The injector and detector temperatures were set at $290^{\circ} \mathrm{C}$. The injection was done in split mode with a 1:100 split ratio. The temperature of the column was initially held at $75^{\circ} \mathrm{C}$ for $1.5 \mathrm{~min}$, increased to $190^{\circ} \mathrm{C}$ at a rate of $8^{\circ} \mathrm{C} / \mathrm{min}$, held at this temperature for $25 \mathrm{~min}$, increased again to $230^{\circ} \mathrm{C}$ at $15^{\circ} \mathrm{C} / \mathrm{min}$, and held for an additional $4.5 \mathrm{~min}$ at $230^{\circ} \mathrm{C}$. Each fatty acid was identified with reference to the retention time of the standards (SigmaAldrich, St. Louis, MO) and quantified with respect to the following internal standards: C13:0 (C10:0 to C17:0) and C19:0 (C18:0 to C18:3).

\section{Statistical Analysis}

Results were analyzed by one-way ANOVA with SAS software (version 9.00; SAS Institute Inc., Cary, NC). A $P$-value of $<0.05$ was considered to be statistically significant.

\section{RESULTS AND DISCUSSION}

The gross composition of $\mathrm{CW}$ is shown in Table 1 . The CW produced on farms had significantly more fat than the CW produced in cheese factories. Heino et al. (2007) observed reduced fat percentages in whey powder when UF was used. Similar to the results observed by Heino et al. (2007), the curd-cutting process for goat cheeses produced on farms was less effective than that for cheeses produced in cheese factories because the temperature and curd particle size are automatically controlled in cheese factories. The technology used in factories improved curd fat recovery.

No differences were observed in protein percentages from $\mathrm{CW}$ produced on farms or in cheese factories (Table 1). Similar protein percentages have been reported (Yang et al., 1994; Casper et al., 1998) for CW from goats, sheep, and cows. Although Heino et al. (2007) reported a small difference in protein percentage depending on the cheese type and cheese production technology, our results demonstrated substantial differences in individual protein composition (Table 2). 
Table 1. Gross composition of goat cheese whey (based on TS) from farms and cheese factories

\begin{tabular}{lccc}
\hline Item & Farm mean & Cheese factory mean & SEM \\
\hline Fat (\%) & $10.5^{\mathrm{a}}$ & 1.2 & 0.90 \\
Protein (\%) & 14.6 & 18.9 & 2.34 \\
Lactose (\%) & 70.5 & 74.2 & 5.11 \\
DM (g/L) & $70.6^{\mathrm{a}}$ & 50.8 & 6.12 \\
\hline
\end{tabular}

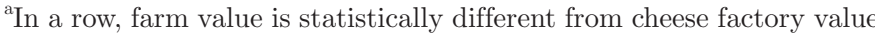
$(P<0.05)$.

No differences were observed in lactose percentages from $\mathrm{CW}$ produced on farms or in cheese factories. Similar results from goat cheeses were reported by Casper et al. (1998). Heino et al. (2007) reported a lower lactose percentage in cow CW.

The protein composition data for $\mathrm{CW}$ are shown in Table 2. Lactoferrin content from the $\mathrm{CW}$ produced on farms was higher than that produced in cheese factories. Steijns and Van Hooijdonk (2000) reported a lower lactoferrin content ( 0.02 to $0.2 \mathrm{~g} / \mathrm{L})$ from $\mathrm{CW}$ derived from cow milk. Hiss et al. (2008) recently reported a lower concentration of lactoferrin in goat milk, but the measurement method (ELISA) was different from that used in the present study. Thermal procedures are used in cheese factories, and the resistance of lactoferrin to thermal denaturation depends on its iron saturation. The more compact conformation of holo-lactoferrin improves its heat stability compared with the more open apo- form of the protein (Paulsson et al., 1993; Kussendrager, 1994). The HTST pasteurization $\left(72^{\circ} \mathrm{C}\right.$, $15 \mathrm{~s})$ used in cheese factories has a limited effect on lactoferrin denaturation (Sanchez et al., 1992). However, Paulsson et al. (1993) and Brisson et al. (2007) reported that HTST pasteurization induces partial denaturation of the native protein, affecting its lower unfolding transition by 40 to $50 \%$. Additionally, Law (1995) reported albumin and lactoferrin denaturation percentages of approximately $20\left(30 \mathrm{~min}\right.$ at $\left.70^{\circ} \mathrm{C}\right)$ and $90 \%\left(30 \mathrm{~min}\right.$ at $\left.80^{\circ} \mathrm{C}\right)$, which is congruent with the data shown in Table 2.

The concentration of caprine serum albumin in goat CW produced on farms was significantly higher than that produced in cheese factories, and was higher than that reported in a previous study on goat CW (Casper et al., 1998). Fox and McSweeney (1998) reported that whey proteins are susceptible to denaturation by several processes, including heat. Law (1995), reporting on goat milk, and Odriozola-Serrano et al. (2006), reporting on cow milk, observed a reduction in BSA in heat-treated milk. The introduction of pasteurization in cheese factories may be responsible for the reduction in caprine serum albumin concentration in the goat $\mathrm{CW}$ from cheese factories observed in this study.
Casein protein is retained in cheese curds; therefore, the percentage in $\mathrm{CW}$ found in our study was very low. Smithers (2008) reported a similar percentage of CN in cow $\mathrm{CW}$ as that observed in goat $\mathrm{CW}(<0.1 \mathrm{mg} / \mathrm{mL})$ in this study. However, Regester and Smithers (1991) reported a higher proportion of $\mathrm{CN}$ in $\mathrm{CW}$ protein concentrate (10 to $25 \%$ of total protein). No other data on the percentage of $\mathrm{CN}$ in $\mathrm{CW}$ is currently available.

$\beta$-Lactoglobulin is the main protein component in goat CW, and no difference was observed in the concentration of this protein in $\mathrm{CW}$ produced on farms or in cheese factories. $\beta$-Lactoglobulin represented approximately $50 \%$ of the total protein present in CW, in agreement with results reported by Regester and Smithers (1991) and, more recently, in a report by Smithers (2008) examining bovine CW. Sannier et al. (2000) reported that the concentration of $\beta$-LG in goat $\mathrm{CW}$ was $3.2 \mathrm{mg} / \mathrm{mL}$, which is similar to our observations (Table 2). $\beta$-Lactoglobulin has been reported to be relatively heat labile (Varnam and Sutherland, 1994), and Odriozola-Serrano et al. (2006) observed a reduction in $\beta-\mathrm{LG}$ after thermal treatment of cow milk. According with Law (1995), $\beta$-LG from goat milk is likely to be more resistant to thermal treatment than $\beta$-LG from cow milk; however, Montilla et al. (1995) reported the opposite results. Differences in AA sequences may explain the different heat stabilities expressed by Law (1995).

The concentration of $\alpha-\mathrm{LA}$ in $\mathrm{CW}$ was not affected by CW origin and represents the second highest concentration of protein in goat CW. Similar concentrations of $\alpha$-LA were observed by Sannier et al. (2000) in goat CW and by Regester and Smithers (1991) and Smithers (2008) in cow CW. Celestino et al. (1997) and Odriozola-Serrano et al. (2006), in cow milk, and Law (1995), in goat CW, reported that the order of heat stability of the whey proteins was $\alpha-L A>\beta-L G>$ serum albumin, in accordance with the results observed

Table 2. Protein composition ( $\mathrm{mg} / \mathrm{mL}$ of whey) of goat cheese whey from farms and cheese factories

\begin{tabular}{lccc}
\hline Item & $\begin{array}{c}\text { Farm mean } \\
(\mathrm{mg} / \mathrm{mL})\end{array}$ & $\begin{array}{c}\text { Cheese factory } \\
\text { mean }(\mathrm{mg} / \mathrm{mL})\end{array}$ & SEM \\
\hline Lactoferrin & $0.39^{\mathrm{a}}$ & 0.15 & 0.04 \\
Caprine serum & $0.60^{\mathrm{a}}$ & 0.39 & 0.04 \\
albumin & & & \\
$\alpha_{\mathrm{s}}$-CN & 0.04 & 0.10 & 0.01 \\
$\beta-\mathrm{CN}$ & $\mathrm{ND}^{1}$ & $\mathrm{ND}$ & - \\
$\kappa-\mathrm{CN}$ & $\mathrm{ND}$ & $\mathrm{ND}$ & - \\
$\beta-\mathrm{LG}$ & 1.99 & 2.07 & 0.15 \\
$\alpha-\mathrm{LA}$ & 1.36 & 1.27 & 0.18 \\
\hline
\end{tabular}

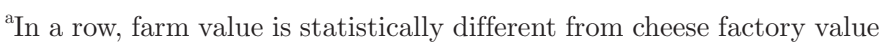
$(P<0.05)$.

${ }^{1} \mathrm{ND}=$ not detected. 
Table 3. Methyl fatty acid composition (\%) of goat cheese whey from farms and cheese factories

\begin{tabular}{lccc}
\hline Item & $\begin{array}{c}\text { Farm mean } \\
\text { \% of total })\end{array}$ & $\begin{array}{c}\text { Cheese factory mean } \\
(\% \text { of total) }\end{array}$ & SEM \\
\hline C14:0 & 14.39 & 15.40 & 1.30 \\
C14:1 & 0.70 & 0.64 & 0.03 \\
C15:1 & 0.38 & 0.42 & 0.02 \\
C16:0 & 40.54 & 39.90 & 1.55 \\
C16:1 & 0.80 & 0.75 & 0.05 \\
C16:2 & 0.89 & 0.76 & 0.05 \\
C17:1 & 0.12 & 0.17 & 0.01 \\
C18:0 & 11.57 & 11.54 & 1.37 \\
C18:1 & 26.00 & 25.80 & 1.89 \\
C18:2 & 2.62 & 2.45 & 0.09 \\
C18:3 & 0.58 & 0.55 & 0.03 \\
C20:0 & 0.23 & 0.32 & 0.01 \\
C20:3 & 0.15 & 0.11 & 0.01 \\
C20:4 & 0.13 & 0.15 & 0.01 \\
C22:2 & 0.22 & 0.29 & 0.02 \\
C23:0 & 0.47 & 0.51 & 0.03 \\
C24:0 & 0.11 & 0.09 & 0.01 \\
C24:4 & 0.10 & 0.15 & 0.01 \\
\hline
\end{tabular}

in this study. When heat treatments were $70^{\circ} \mathrm{C}$, Law (1995) and Montilla et al. (1995) reported a high thermal stability of $\alpha$-LA, in accordance with the results displayed in Table 2.

Table 3 compares the fatty acid percentages in CW produced on farms and in factories. No significant origin-dependent effects were observed. Similar results were reported by Fidler et al. (1998) for pasteurized human milk. The main fatty acids reported in Table 3 were also reported by Bañón et al. (2006) for goat milk, although Soryal et al. (2005) observed seasonal or breed effects with goat milk as well. The proportion of essential linolenic acid, which is particularly susceptible to peroxidation, was not affected by the pasteurization process used in factories. Wardell et al. (1981) determined the fatty acid composition of fresh and pasteurized milk from 8 human mothers, but reported only 7 fatty acids (C14:0, C16:0, C18:0, C16:1n-7, C18:1n-9, C18:2n-6, and C18:3n-3). They also reported a statistically significant $(22 \%)$ decrease in linolenic acid in milk heated to $62.5^{\circ} \mathrm{C}$ for $30 \mathrm{~min}$. These results are opposite the results observed in the present study and those reported by Fidler et al. (1998), even though the pasteurization conditions were similar in all 3 studies. Polyunsaturated fatty acids are sensitive to light, oxygen exposure, and temperature, and in milk, they are incorporated into fat globules. If the milk is handled carefully (no centrifugation or homogenization), intact milk fat globule membranes protect the fatty acids. In the present study, CW from cheese factories was derived from milk exposed to increased temperature, but not to light, oxygen, or pressure, likely resulting in preservation of the fatty acid composition of the milk. The comparable fatty acid composition between milk and CW demonstrates that the cheese-making procedures did not affect fatty acid composition during the transition from milk to CW. However, this lipolysis phenomenon might occur during ripening.

\section{CONCLUSIONS}

The origin of $\mathrm{CW}$ (farms or cheese factories) has important effects on CW composition, including differences in individual proteins. We must be aware of these differences when CW is used in biotechnology or animal nutrition, or for other uses.

\section{REFERENCES}

Bañón, S., R. Vila, A. Price, E. Ferrandini, and M. D. Garrido. 2006. Effects of goat milk or milk replacer diet on meat quality and fat composition of suckling goat kids. Meat Sci. 72:216-221.

Basch, J. J., F. W. Douglas, L. G. Procino, V. H. Holsinger, and H. M. Farrell. 1985. Quantification of caseins and whey proteins of processed milks and whey protein concentrates application of gel electrophoresis, and comparison with Harland-Ashworth procedure. J. Dairy Sci. 68:23-31.

Brisson, G., M. Britten, and Y. Pouliot. 2007. Effect of iron saturation on the recovery of lactoferrin in rennet whey coming from heattreated skim milk. J. Dairy Sci. 90:2655-2664.

Bullerman, L. B., and E. C. Berry. 1966. Use of cheese whey for vitamin $\mathrm{B}_{12}$ production. I. Whey solids and yeast extract levels. Appl. Microb. 14:353-355.

Casper, J. L., W. L. Wendorff, and D. L. Thomas. 1998. Seasonal changes in protein composition of whey from commercial manufacture of caprine and ovine specialty cheeses. J. Dairy Sci. 81:3117-3122.

Celestino, E. L., M. Iyer, and H. Roginski. 1997. The effect of refrigerated storage of raw milk on the quality of whole milk powder stored for different periods. Int. Dairy J. 7:119-127.

Chin, S. F., W. Liu, J. M. Storkson, Y. Ha, and M. W. Pariza. 1992. Dietary sources of conjugated dienoic isomers of linoleic acid, a newly recognized class of anticarcinogens. J. Food Compost. Anal. 5:185-197.

Fidler, N., T. U. Sauerwald, B. Koletzko, and H. Demmelmair. 1998. Effects of human milk pasteurization and sterilization on available fat content and fatty acid composition. J. Pediatr. Gastroenterol. Nutr. 27:317-322.

Fox, P. F., and P. L. H. McSweeney. 1998. Dairy Chemistry and Biochemistry. Blackie Academic and Professional, London, UK.

Fresno, M., N. Darmanin, J. Capote, and J. M. García. 1992. Characterization of cheese produced by traditional methods in the Canary Islands. Arch. Zootec. 41:657-660.

Heino, A., J. Uusi-Rauva, P. Rantamäki, and O. Vainen. 2007. Functional properties of native and cheese whey protein concentrate powders. Int. J. Dairy Technol. 60:277-285.

Hiss, S., T. Meyer, and H. Sauerwein. 2008. Lactoferrin concentrations in goat milk throughout lactation. Small Rumin. Res. 80:87-90.

Kaur, G., P. S. Panesar, M. B. Bera, and H. Kumar. 2009. Hydrolysis of whey lactose using CTAB-permeabilized yeast cells. Bioprocess Biosyst. Eng. 32:63-67.

Kussendrager, K. D. 1994. Effects of heat treatment on structure and iron-binding capacity of bovine lactoferrin. Pages 133-146 in IDF Bulletin: Indigenous Antimicrobial Agents of Milk: Recent Developments. Int. Dairy Fed., Brussels, Belgium.

Laemmli, U. K. 1970. Cleavage of structural proteins during the assembly of the head of bacteriophage T4. Nature 227:680-685.

Law, A. J. R. 1995. Heat denaturation of bovine, caprine and ovine whey proteins. Milchwissenschaft 50:384-388.

Montilla, A., E. Balcones, A. Olano, and M. M. Calvo. 1995. Influence of heat treatments on whey protein denaturation and rennet 
clotting properties of cow's and goat's milk. J. Agric. Food Chem. 43:1908-1911.

Odriozola-Serrano, I., S. Bendicho-Porta, and O. Martín-Belloso. 2006. Comparative study on shelf life of whole milk processed by highintensity pulsed electric field or heat treatment. J. Dairy Sci. 89:905-911.

Paulsson, M. A., U. Svensson, A. R. Kishore, and A. S. Naidu. 1993. Thermal behavior of bovine lactoferrin in water and its relation to bacterial interaction and antibacterial activity. J. Dairy Sci. 76:3711-3720.

Regester, G. O., and G. W. Smithers. 1991. Seasonal changes in the $\beta$-lactoglobulin, $\alpha$-lactalbumin, glycomacropeptide, and casein content of whey protein concentrate. J. Dairy Sci. 74:796-802.

Sanchez, L., J. M. Peiro, H. Castillo, M. D. Perez, J. M. Ena, and M. Calvo. 1992. Kinetic parameters for denaturation of bovine milk lactoferrin. J. Food Sci. 57:873-879.

Sannier, F., S. Bordenave, and J. M. Piot. 2000. Purification of goat $\beta$-lactoglobulin from whey by an ultrafiltration membrane enzymic reactor. J. Dairy Res. 67:43-51.

Siso, M. I. G. 1996. The biotechnological utilization of cheese whey: A review. Bioresour. Technol. 57:1-11.
Smithers, G. W. 2008. Whey and whey proteins. From 'gutter-to-gold.' Int. Dairy J. 18:695-704

Soryal, K., F. A. Beyene, S. Zeng, B. Bah, and K. Tesfai. 2005. Effect of goat breed and milk composition on yield, sensory quality, fatty acid concentration of soft cheese during lactation. Small Rumin. Res. 58:275-281.

Steijns, J. M., and A. C. M. Van Hooijdonk. 2000. Occurrence, structure, biochemical properties, and technological characteristics of lactoferrin. Br. J. Nutr. 84(Suppl. 1):S11-S17.

Varnam, A. H., and J. P. Sutherland. 1994. Milk and milk products. Pages 42-88 in Technology Chemistry and Microbiology. Chapman and Hall, London, UK.

Wardell, J. M., C. M. Hill, and S. W. D'Souza. 1981. Effect of pasteurization and of freezing and thawing human milk on its triglyceride content. Acta Paediatr. Scand. 70:467-471.

Yang, S. T., H. Zhu, Y. Li, and G. Hong. 1994. Continuous propionate production from whey permeate using a novel fibrous bed bioreactor. Biotechnol. Bioeng. 43:1124-1130. 